ISSN 0258-7122

Bangladesh J. Agril. Res. 39(1): 143-150, March 2014

\title{
EFFECT OF HYDROPRIMING METHOD ON MAIZE (Zea mays) SEEDLING EMERGENCE
}

\author{
K. U. AHAMMAD ${ }^{1}$, M. M. RAHMAN ${ }^{2}$ AND M. R. ALI ${ }^{3}$
}

\begin{abstract}
The research work was carried out at the Seed Laboratory of Agronomy Department of Bangladesh Agricultural University, Mymensingh during the period from February to April in 2008 to find out the effect of hydropriming methods on maize seedling emergence. The hydropriming methods were- $T_{1}$ (Non-priming), $\mathrm{T}_{2}$ (14 hours soaking + drying + storing), $\mathrm{T}_{3}$ (18 hours soaking + drying + storing), $\mathrm{T}_{4}(22$ hours soaking + drying + storing $), \mathrm{T}_{5}$ (14 hours soaking + surface drying), $\mathrm{T}_{6}$ (18 hours soaking + surface drying), and $\mathrm{T}_{7}$ (22 hours soaking + surface drying). Effect of different hydropriming methods on seedling emergence performance of maize was evaluated at two moisture levels viz., $30 \%$ and $60 \%$ moisture of saturated sand in the experiment. Germination percentage, germination index and mean germination time were influenced significantly by hydropriming methods. The highest germination percentage, germination index, and lowest mean germination time were recorded with $\mathrm{T}_{6}(18$ hours soaking + surface drying).
\end{abstract}

Keywords: Hydropriming, maize, seedling emergence.

\section{Introduction}

Good seedling establishment is an important prerequisite for successful crop production and this is particularly true for crops, such as maize (Zea mays L.) which do not have the capacity to adjust to sub-optimal stand by tillering (Finch Savage et al., 2004). Maize is one of the important cereal crops of Bangladesh which can be produced successfully by priming. Harris et al. (1999) demonstrated that on-farm seed priming by soaking seeds overnight in water followed by surface drying and then sowing in the normal way markedly improved the stand establishment and early vigour of maize. Rapid establishment and high vigour also resulted in faster development, earlier flowering and maturity, and higher yields. Seed priming can be a simple solution towards expected stand establishment (Harris et al., 2001).

Parera and Cantliffe (1994) and McDonald (1999) emphasized that hydropriming is the simplest approach to hydrating seeds and minimizes the use of chemicals. Hydropriming involves allowing seeds to absorb sufficient water to initiate metabolic process but insufficient water to allow completion of

\footnotetext{
${ }^{1}$ Senior Scientific Officer, RARS, Bangladesh Agricultural Research Institute (BARI), Jessore, ${ }^{2}$ Professor, Department of Agronomy, Bangladesh Agricultural University (BAU), Mymensingh and ${ }^{3}$ Senior Scientific Officer, RARS, BARI, Jamalpur, Bangladesh.
} 
germination. When seeds are imbibed, the lag period before radical emergence is considerably reduced and improved the rate and uniformity of germination. Singh (1995) and Shivankar et al. (2003) observed that hydro priming practically ensured rapid and uniform germination accompanied with low abnormal seedling percentage. They further noted that hydropriming had high potential in improving field emergence and ensured early flowering and harvesting under stress condition, especially in dry areas. Hydropriming is being used to reduce the germination time to get synchronized germination, improve germination rate and better seedling in many crops such as maize, soybean, wheat, lentil, chickpea, mungbean, cowpea, etc. (Singh, 1995).

Farmers can prime their own seed if they know the maximum length of time for which their seeds can be soaked before seed or seedling damage occur. However, the priming techniques of maize are not well established in Bangladesh. Although quite a good number of works have been done on seed priming of maize abroad but under Bangladesh condition, such works are scanty. Therefore, the present study was undertaken to study the effect of hydropriming methods on maize seedling emergence.

\section{Materials and Method}

The research was conducted at the Seed Laboratory of Agronomy Department of Bangladesh Agricultural University, Mymensingh during the period from February to April in 2008 to find out the effect of hydropriming methods on maize seedling emergence. Seeds of BARI Hybrid Maize-5 (BHM-5) were used as testing material. The experiment includes seven priming treatments viz., $\mathrm{T}_{1}=$ Non-priming (Control), $\mathrm{T}_{2}=14$ hours soaking + drying + storing, $\mathrm{T}_{3}=18$ hours soaking + drying + storing, $\mathrm{T}_{4}=22$ hours soaking + drying + storing, $\mathrm{T}_{5}=14$ hours soaking + surface drying, $\mathrm{T}_{6}=18$ hours soaking + surface drying, $\mathrm{T}_{7}=22$ hours soaking + surface drying. The experiment was laid out in completely randomized design with three replications. Priming was done by soaking seeds in water for the period as per experimental specification. In case of soaking + drying + storing treatments seeds were dried back to the original moisture content and stored in plastic containers for two months. While in case of soaking + surface drying treatments, seeds were surface dried for two hours before placing for seedling emergence test. Plastic pots $(21 \mathrm{~cm}$ diameter and $9 \mathrm{~cm}$ depth) were filled with $2.5 \mathrm{~kg}$ of dried sand. Two levels of moisture viz., $30 \%$ and $60 \%$ moisture content of the saturated sand was created in the pot sand by adding 195 and $390 \mathrm{ml}$ distilled water, respectively. In each pot, 50 treated seeds were placed at $2 \mathrm{~cm}$ depth in sand maintaining equal distance from seed to seed. The experiment was trialled twice. Trial-1 was conducted on 10 April 2008 and trial2 on 20 April 2008. The seedling emergence performance was tested at $30 \%$ and 
$60 \%$ moisture content of saturated sand. No extra moisture was added in the pot during the test period. Data on germination percentage, germination index, and mean germination time were recorded as follows:

i. Germination percentage: The seedlings were counted daily until complete emergence. Germination was calculated in percentage using the following formula:

$\%$ Germination $=\frac{\text { Number of seeds germinated }}{\text { Number of seeds sown }} \times 100$

ii. Germination index: The germination index (GI) was calculated following the formula of AOSA (1983).

iii. Mean germination time: The mean germination time (days) was calculated according to the formula of Scott et al. (1984).

Data were subjected to statistical analysis using ANOVA technique through computer based statistical package programme MSTAT-C. Arc sine and square root transformations of data were done for percentage data where applicable before the analysis (Gomez and Gomez, 1984). Mean comparison was done by Duncun's Multiple Range Test (DMRT).

\section{Results}

\section{Germination percentage}

Hydropriming method significantly influenced the germination of maize seed when tested both at 30 and $60 \%$ moisture levels in the two trials (Table 1). On an average, the highest germinations were recorded with $\mathrm{T}_{6}$ (18 hours priming + surface drying) which were $84 \%$ and $95 \%$ at $30 \%$ and $60 \%$ levels of moisture, respectively. The lowest germination was recorded with $\mathrm{T}_{1}$ (Non-priming), which were $40 \%$ and $76 \%$ at $30 \%$ and $60 \%$ levels of moisture, respectively. It was noted from the Table 1 that the germination enhancement for $\mathrm{T}_{6}$ was higher by $44 \%$ and $19 \%$ over $\mathrm{T}_{1}$ at $30 \%$ and $60 \%$ moisture level, respectively.

\section{Germination index}

Germination index showed significant variation due to hydropriming methods both at $30 \%$ and $60 \%$ moisture levels in the two trials (Table 2). Average germination index was highest in $\mathrm{T}_{6}$ (18 hours priming + surface drying), which were 24.96 and 29.83 at $30 \%$ and $60 \%$ levels of moisture, respectively. The lowest value was found for $\mathrm{T}_{1}$ (Non-priming), which were 8.36 and 18.82 at $30 \%$ and $60 \%$ level of moisture, respectively. It was observed that germination index at $\mathrm{T}_{6}$ was higher by $199 \%$ and $59 \%$ over $\mathrm{T}_{1}$ at $30 \%$ and $60 \%$ moisture level, respectively. 
Table 1. Effect of hydropriming methods on germination percentage of maize seed.

\begin{tabular}{|c|c|c|c|c|c|c|}
\hline \multicolumn{7}{|c|}{ Germination percentage } \\
\hline \multirow{2}{*}{ Treatment } & \multicolumn{3}{|c|}{$30 \%$ moisture } & \multicolumn{3}{|c|}{$60 \%$ moisture } \\
\hline & Trial-1 & Trial-2 & Mean & Trial-1 & Trial-2 & Mean \\
\hline $\mathrm{T}_{1}$ & $41(38.41) \mathrm{e}$ & 38 (36.71)f & $40(37.56) \mathrm{g}$ & $76(8.74) \mathrm{e}$ & $76(8.72) \mathrm{e}$ & $76(8.72) \mathrm{e}$ \\
\hline $\mathrm{T}_{2}$ & $44(40.09) \mathrm{e}$ & $42(38.97) f$ & $43(39.53) \mathrm{f}$ & $82(9.06) \mathrm{d}$ & $80(8.92) \mathrm{d}$ & $81(8.99) d$ \\
\hline $\mathrm{T}_{3}$ & $56(46.74) \mathrm{c}$ & $53(44.89) \mathrm{d}$ & $54(45.81) \mathrm{d}$ & $87(9.35) c$ & $86(9.25) c$ & $87(9.30) c$ \\
\hline $\mathrm{T}_{4}$ & $50(43.41) \mathrm{d}$ & $48(42.31) \mathrm{e}$ & $49(42.86) \mathrm{e}$ & $85(9.20) \mathrm{cd}$ & $83(9.11) c$ & $84(9.16) c$ \\
\hline $\mathrm{T}_{5}$ & $81(62.17) b$ & $74(57.26) \mathrm{c}$ & $78(59.72) \mathrm{c}$ & $92(9.57) \mathrm{b}$ & $89(9.43) b$ & $90(9.50) \mathrm{b}$ \\
\hline $\mathrm{T}_{6}$ & $85(65.17) \mathrm{a}$ & $82(62.63) \mathrm{a}$ & $84(63.89) \mathrm{a}$ & $96(9.80) \mathrm{a}$ & $94(9.68) \mathrm{a}$ & 95 (9.74)a \\
\hline $\mathrm{T}_{7}$ & 83 (63.37)ab & $78(60.08) b$ & $81(61.73) b$ & 93 (9.66)ab & $92(9.59) \mathrm{ab}$ & 93 (9.63)ab \\
\hline$S \bar{x}$ & 0.925 & 0.793 & 0.493 & 0.059 & 0.054 & 0.051 \\
\hline Level of significance & $* *$ & $* *$ & $* *$ & $* *$ & $* *$ & $* *$ \\
\hline $\mathrm{CV}(\%)$ & 3.12 & 2.80 & 1.70 & 1.10 & 1.01 & 0.96 \\
\hline
\end{tabular}

Figures in parentheses are arc sine transformed values of germination percentage at $30 \%$ moisture and square root transformed values at $60 \%$ moisture level.

Figures with similar letter(s) or without letter within the column do not differ significantly whereas figures with dissimilar letter(s) differ significantly at 0.05 level of probability by DMRT.

$* *=$ Significant at 0.01 level of probability. 
Table 2. Effect of hydropriming methods on germination index of maize seed.

\begin{tabular}{|c|c|c|c|c|c|c|}
\hline \multicolumn{7}{|c|}{ Germination index } \\
\hline \multirow{2}{*}{ Treatment } & \multicolumn{3}{|c|}{$30 \%$ moisture } & \multicolumn{3}{|c|}{$60 \%$ moisture } \\
\hline & Trial-1 & Trial-2 & Mean & Trial-1 & Trial-2 & Mean \\
\hline $\mathrm{T}_{1}$ & $8.88 \mathrm{~d}$ & $7.83 \mathrm{e}$ & $8.36 \mathrm{~d}$ & $19.14 \mathrm{~g}$ & $18.49 \mathrm{f}$ & $18.82 \mathrm{~g}$ \\
\hline $\mathrm{T}_{2}$ & $9.37 \mathrm{~cd}$ & 8.74 de & $9.06 \mathrm{~d}$ & $20.64 \mathrm{f}$ & $20.38 \mathrm{e}$ & $20.51 \mathrm{f}$ \\
\hline $\mathrm{T}_{3}$ & $10.85 \mathrm{c}$ & $10.33 \mathrm{c}$ & $10.59 \mathrm{c}$ & $22.55 \mathrm{~d}$ & $22.17 \mathrm{~cd}$ & $22.36 \mathrm{~d}$ \\
\hline $\mathrm{T}_{4}$ & $9.81 \mathrm{~cd}$ & $9.25 \mathrm{~d}$ & $9.53 \mathrm{~cd}$ & $21.61 \mathrm{e}$ & $21.20 \mathrm{de}$ & $21.41 \mathrm{e}$ \\
\hline $\mathrm{T}_{5}$ & $21.49 \mathrm{~b}$ & $21.16 \mathrm{~b}$ & $21.33 \mathrm{~b}$ & $23.59 \mathrm{c}$ & $22.82 \mathrm{c}$ & $23.20 \mathrm{c}$ \\
\hline $\mathrm{T}_{6}$ & $25.24 \mathrm{a}$ & $24.66 \mathrm{a}$ & $24.96 \mathrm{a}$ & $30.74 \mathrm{a}$ & $28.92 \mathrm{a}$ & $29.83 \mathrm{a}$ \\
\hline $\mathrm{T}_{7}$ & $24.30 \mathrm{a}$ & $23.67 \mathrm{a}$ & $23.99 \mathrm{a}$ & $28.88 \mathrm{~b}$ & $27.30 \mathrm{~b}$ & $28.09 \mathrm{~b}$ \\
\hline$S \bar{x}$ & 0.483 & 0.332 & 0.383 & 0.219 & 0.322 & 0.209 \\
\hline Level of significance & $* *$ & $* *$ & $* *$ & $* *$ & $* *$ & $* *$ \\
\hline $\mathrm{CV}(\%)$ & 5.33 & 3.81 & 4.31 & 1.59 & 2.42 & 1.55 \\
\hline
\end{tabular}

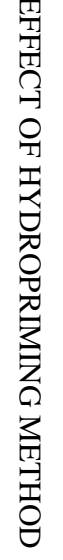

Figures with similar letter(s) or without letter within the column do not differ significantly whereas figures with dissimilar letter(s) differ significantly at 0.05 level of probability by DMRT.

** = Significant at 0.01 level of probability. 
Table 3. Effect of hydropriming methods on mean germination time of maize seed.

\begin{tabular}{|c|c|c|c|c|c|c|}
\hline \multicolumn{7}{|c|}{ Mean germination time (day) } \\
\hline \multirow{2}{*}{ Treat } & \multicolumn{3}{|c|}{$30 \%$ moisture } & \multicolumn{3}{|c|}{$60 \%$ moisture } \\
\hline & Trial-1 & Trial-2 & Mean & Trial-1 & Trial-2 & Mean \\
\hline $\mathrm{T}_{1}$ & $5.15 \mathrm{a}$ & $5.23 \mathrm{a}$ & $5.19 \mathrm{a}$ & $4.72 \mathrm{a}$ & $4.78 \mathrm{a}$ & $4.75 \mathrm{a}$ \\
\hline $\mathrm{T}_{2}$ & $5.00 \mathrm{a}$ & $4.98 \mathrm{~b}$ & $4.99 \mathrm{~b}$ & $4.33 \mathrm{~b}$ & $4.44 \mathrm{ab}$ & $4.39 \mathrm{~b}$ \\
\hline $\mathrm{T}_{3}$ & $4.72 \mathrm{~b}$ & $4.80 \mathrm{~b}$ & $4.76 \mathrm{c}$ & $4.18 \mathrm{c}$ & $4.23 \mathrm{~b}$ & $4.21 \mathrm{c}$ \\
\hline $\mathrm{T}_{4}$ & $4.81 \mathrm{~b}$ & $4.89 \mathrm{~b}$ & $4.85 \mathrm{bc}$ & $4.24 \mathrm{c}$ & $4.28 \mathrm{~b}$ & $4.26 \mathrm{c}$ \\
\hline $\mathrm{T}_{5}$ & $4.10 \mathrm{c}$ & $4.15 \mathrm{c}$ & $4.13 \mathrm{~d}$ & $3.38 \mathrm{~d}$ & $3.46 \mathrm{c}$ & $3.42 \mathrm{~d}$ \\
\hline $\mathrm{T}_{6}$ & $3.51 \mathrm{~d}$ & $3.60 \mathrm{~d}$ & $3.56 \mathrm{e}$ & $3.18 \mathrm{f}$ & $3.26 \mathrm{c}$ & $3.22 \mathrm{f}$ \\
\hline $\mathrm{T}_{7}$ & $3.64 \mathrm{~d}$ & $3.70 \mathrm{~d}$ & $3.67 \mathrm{e}$ & $3.28 \mathrm{e}$ & $3.35 \mathrm{c}$ & $3.32 \mathrm{e}$ \\
\hline$S \bar{X}$ & 0.054 & 0.068 & 0.057 & 0.019 & 0.036 & 0.023 \\
\hline Level of significance & $* *$ & $* *$ & $* *$ & $* *$ & $* *$ & $* *$ \\
\hline CV (\%) & 2.10 & 2.62 & 2.20 & 0.82 & 1.58 & 1.01 \\
\hline
\end{tabular}

Figures with similar letter(s) or without letter within the column do not differ significantly whereas figures with dissimilar letter(s) differ significantly at 0.05 level of probability by DMRT.

$* *=$ Significant at 0.01 level of probability.

$\mathrm{T}_{1}=$ Non priming (control), $\mathrm{T}_{2}=14$ hours soaking + drying + storing

$\mathrm{T}_{3}=18$ hours soaking + drying + storing, $\mathrm{T}_{4}=22$ hours soaking + drying + storing .

$\mathrm{T}_{5}=14$ hours soaking + surface drying, $\mathrm{T}_{6}=18$ hours soaking + surface drying.

$\mathrm{T}_{7}=22$ hours soaking + surface drying. 


\section{Mean germination time}

Hydropriming method influenced significantly the mean germination time of maize seed both at 30\% and 60\% moisture level in both the trials (Table 3). Average mean germination time was lowest at $\mathrm{T}_{6}(18$ hours priming + surface drying), which were 3.56 and 3.22 day at 30 and $60 \%$ levels of moisture, respectively. The mean germination time was found highest for $\mathrm{T}_{1}$ (Nonpriming), which were 5.19 and 4.75 day at $30 \%$ and $60 \%$ levels of moisture, respectively. Further, it was noted that mean germination time decreased at $\mathrm{T}_{6}$ by 31 and $33 \%$ over $\mathrm{T}_{1}$ at $30 \%$ and $60 \%$ moisture level, respectively.

\section{Discussion}

The emergence of maize seed was evaluated in terms of germination percentage, germination index, and mean germination time in the experiment. Seeds soaked for 18 hours allow most important physiological activities to be performed properly resulting in best emergence performance. This result corroborates the findings of Harris (2003) who stated that 18 hours is the optimum duration for maize seed priming. The present study concludes that priming of maize seed requires 18 hours soaking in water for better emergence.

In many seed industries, for priming, seeds are soaked in water and then dried back to their original moisture level. This primed seeds are stored for a long period before sowing. In the present study, the primed seed was stored for two months before sowing. This primed stored seed showed poor emergence than the seeds that were sown immediately after surface drying. The poor performance of primed stored seed may be due to quality deterioration of seed during drying and storage. This result is similar with the findings of Hardegree (1994) who found that storing of primed seed decreased germination. Similar results was also found by Heydecker and Coolbear (1997); Adetumbi et al. (2009); Liu et al. (1996); Sangakkara (1995) and Nascimento (2002). Although many reports support that primed and stored seeds can give better emergence, in our study this was not achieved because deterioration of seed quality occurred in primed stored seed. Primed stored seed gave poor emergence than the seeds that were soaked in water and instantly sown after two hours of surface drying. So, it may be concluded that 18 hours soaking followed by two hours surface drying before sowing is suitable for maize seed priming.

\section{Conclusion}

From the results of the present study, it may be concluded that soaking of seeds in water for 18 hours followed by 2 hours surface drying could be used as priming method for maize seeds. 


\section{References}

Adetumbi, J. A., A. C. Odiyi , S. A. Olakojo and M. A. Adebisi. 2009. Effect of storage materials and environments on drying and germination quality of maize (Zea mays L.). EJEAFChe. 8(11): 1140-1149.

AOSA (Association of Official Seed Analysts). 1983. Seed Vigor Testing Handbook. Contribution No. 32 to the Handbook on Seed Testing.

Finch-Savage, W. E., K. C. Dent and L. J. Clark. 2004. Soak conditions and temperature following sowing influence the response of maize (Zea mays L.) seeds to on-farm priming (Pre-sowing seed soak). Field Crops Res. 90(2/3): 361-374.

Gomez K. A. and A.A. Gomez. 1984. Statistical Procedures for Agriculture Research. Intl. Rice. Res. Inst., Philippines. Pp.187-411.

Hardegree, S. P. 1994. Drying and storage effects on germination of primed grass seeds. J. Range Manage. 47(3):196-199.

Harris, D., A. Joshi, P.A. Khan, P. Gothakar, and P. S. Sodhi. 1999. On-farm seed priming in semi-arid agriculture: Development and evaluation in corn, rice and chickpea in India using participatory methods. Exp. Agric. 35: 15-29.

Harris, D., A. K. Pathan, P. Gothkar, A. Joshi, W. Chivasa and P. Nyamudeza. 2001. Onfarm seed priming: using participatory methods to revive and refine a key technology. Agril. Systems. 69: 151-164.

Harris, D. 2003. Increasing yields of rainfed crops in Africa using 'on-farm' seed priming. Afr. Crop Sci. Conf. Proceed. 6: 26-30.

Heydecker, W. and P. Coolbear. 1977. Seed treatments for improved performance-survey and attempted prognosis. Seed Sci. Technol. 5: 353-425.

Liu, Y., R.J. Bino, W.J. Van der Burg, S.P.C. Groot and H.W.M. Hilhorst.1996. Effects of osmotic priming on dormancy and storability of tomato (Lycopersicon esculentum Mill.) seeds. Seed Sci. Res. 6: 49-55.

McDonald, M. B. 1999. Seed deterioration: Physiology, repair and assessment. Seed Sci. Technol. 27: 177-237.

Nascimento, W. M. 2002. Germination of primed muskmelon seeds during storage. Revista Brasileira de Sementes 24(1): 158-161.

Parera C. A. and D. J. Cantliffe. 1994. Pre-sowing seed priming. Hort. Rev. 16: 109-141.

Sangakkara, U.R. 1995. Influence of seed ripeness, sarcotesta, drying and storage on germinability of papaya (Carica papaya L.) seed. Pertanika J. Tropic. Agril. Sci. 18(3):193-199.

Scott, S. L., R. A. Jones and W. A. Williams. 1984. Review of data analysis methods for seed germination. Crop Sci. 24: 1192-1198.

Shivankar, R. S., D. B. Deore and N. G. Zode. 2003. Effect of pre-sowing seed treatment on establishment and seed yield of sunflower. J. Oilseed Res. 20: 299-300.

Singh, B. G. 1995. Effect of hydration dehydration seed treatments on vigour and yield of sunflower. Indian J. Plant. Physiol. 38: 66-68. 